\title{
Аналіз клінічного перебігу та операційного лікування пацієнтів із критичною ішеміею нижньої кінцівки
}

\begin{abstract}
Мета роботи: проаналізувати гендерні, клінічні, анамнестичні особливості перебігу оклюзійних захворювань артерій нижніх кінцівок у пацієнтів, яким були виконані нетравматичні ампутації.

Матеріали і методи. Проведений аналіз клінічного обстеження та лікування 189 пацієнтів з облітеруючими захворюваннями артерій нижніх кінцівок. У ретроспективний етап дослідження було включено 115 пацієнтів, яким було проведено ампутації нижніх кінцівок на різному рівні впродовж 2010-2014 рр. Проспективний етап дослідження включав 74 пацієнтів, в яких ампутація нижньої кінцівки була проведена впродовж 2015-2018 pр.

Результати досліджень та їх обговорення. Достовірно не відрізнялись основні причини хронічної ішемії нижньої кінцівки, які призвели до розвитку некротичних змін: частота облітеруючого атеросклерозу та цукрового діабету у хворих обох етапів була однакова. У пацієнтів проспективного етапу був менш тривалий анамнез захворювання (p<0,05), достовірно зменшилась кількість пацієнтів, у яких ампутацію виконували після невдалої відкритої чи ендоваскулярної реконструктивної операції на судинах $(\mathrm{p}<0,05)$. Зменшилась кількість ампутацій на рівні стегна $(\mathrm{p}<0,001)$, зросла частота ампутацій на рівні колінного суглоба (p<0,001). Частота проведення ощадних ампутацій стопи змінилась недостовірно (p>0,05). Недостовірно зменшилась кількість пацієнтів, у яких виникала потреба у реампутаціях (p>0,05).

Найбільш частою причиною нетравматичних ампутацій кінцівок є цукровий діабет типу 2. В період з 2015 по 2018 рр. зменшилась кількість ампутацій вище коліна. Недостовірно зменшилась кількість пацієнтів, у яких виникала потреба у реампутаціях ( $\mathrm{p}>0,05)$.
\end{abstract}

Ключові слова: оклюзійні захворювання; критична ішемія нижніх кінцівок; ампутація.

Постановка проблеми і аналіз останніх досліджень та публікацій. Незважаючи на успіхи сучасної ангіології в лікуванні судинних захворювань артерій кінцівок, ампутація зустрічається нерідко і виконується як останній захід в комплексному лікуванні хворих з оклюзійними захворюваннями артерій нижніх кінцівок. Критична ішемія нижніх кінцівок $є$ невирішеною проблемою сучасної серцево-судинної хірургії. Основними завданнями лікування критичної ішемії кінцівки слід вважати: збереження життя, збереження кінцівки, збереження колінного суглоба в разі неминучості великої ампутації (рівень доказовості C) [1, 2].

Визначення рівня ампутації залишається актуальною проблемою. Нерідко виникає конфлікт між бажанням хворого зберегти максимально довгий сегмент кінцівки та прагненням хірурга провести ампутацію з гарантією загоєння рани [3].

В останні десятиліття відмічається тенденція до максимально можливого збереження кінцівки. При цьому повинен враховуватися той факт, що рана кукси загоїться первинним натягом. Збереження колінного суглоба і достатньої довжини гомілкових кісток дозволяє особам похилого віку і ослабленим хворим використовувати легкі протези і самостійно пересуватись. У пацієнтів 3 добре сформованою куксою після ампутації нижче коліна більше шансів повернутись до самостійно- го пересування, ніж у хворих після ампутації вище коліна, шанси самостійно рухатись у яких не перевищують 50 \%. При прагненні знизити рівень ампутації операцію нерідко виконують в умовах недостатньої мікроциркуляції, що призводить до збільшення кількості післяопераційних ускладнень. У 15 \% пацієнтів виникає потреба ампутації вище коліна, 10 \% хворих гине у періопераційному періоді. Отже, актуальною лишається розробка методів визначення адекватності рівня ампутації $[4,5]$.

Мета роботи: проаналізувати гендерні, клінічні, анамнестичні особливості перебігу оклюзійних захворювань артерій нижніх кінцівок у пацієнтів, яким були виконані нетравматичні ампутації.

Матеріали і методи. Нами проведений аналіз клінічного обстеження та лікування 189 пацієнтів з облітеруючими захворюваннями артерій нижніх кінцівок різного генезу. Критеріями включення хворих у дослідження були: інформована згода хворих, вік від 18 років, клінічні та інструментальні ознаки некрозу тканин нижньої кінцівки, консультація ангіохірурга з констатацією неможливості виконати відкриту чи ендоваскулярну реваскуляризацію. Критеріями виключення були: злоякісні новоутворення, годування груддю чи вагітність, гострі ускладнення цукрового діабету, 
тяжка хронічна ниркова дисфункція, неврастенія, неадекватна поведінка.

У ретроспективний етап дослідження було включено 115 пацієнтів, яким були проведені ампутації нижніх кінцівок на різному рівні в умовах клінічного відділення кафедри хірургії № 1 ІФНМУ впродовж 2010-2014 рр. Проспективний етап дослідження включав 74 пацієнти, в яких ампутація нижньої кінцівки була проведена впродовж 2015-2018 pр. з застосуванням запропонованих нами тактичних і методичних підходів до операцій та ведення періопераційного періоду.

Результати досліджень та їх обговорення. Ретроспективний етап. Основними причинами, які спричиняли головну потребу в ампутації, був облітеруючий атеросклероз $(30,7 \pm 3,4) \%$ та оклюзійні ураження артерій на грунті цукрового діабету $(69,3 \pm 3,35) \%$. Аналізуючи розподіл пацієнтів за віком і статтю, нами було встановлено, що впродовж 2010-2014 рр. ампутацій було виконано 34 жінкам $(29,6 \pm 4,26) \%$ та 81 чоловікові $(70,4 \pm 4,26) \%$. Гендерні відмінності достовірно відрізнялися $(\mathrm{p}<0,001)$.

Найменша кількість пацієнтів $(4,3 \pm 1,9)$ \% вказувала, що перші прояви облітеруючого захворювання судин вони відмітили впродовж п'яти останніх років. Потрібно вказати, що у всіх цих пацієнтів, критична ішемія нижньої кінцівки розвинулась на грунті цукрового діабету 2 типу. Дев'ятнадцять пацієнтів $(16,5 \pm 3,5) \%$ мали анамнез захворювання в межах десяти років, серед них не відмічали достовірної різниці між статтю (p>0,05). У більшості пацієнтів $(52,2 \pm 4,7)$ \% потреба у проведенні ампутації виникла після 16 i більше років захворювання, при чому спостерігалась недостовірна різниця між кількістю жінок $(50,0 \pm 8,57) \%$ та чоловіків $(53,1 \pm 5,5) \%$.

У 36 пацієнтів $(31,3 \pm 4,3)$ \% причиною ампутацій був облітеруючий атеросклероз судин нижніх кінцівок, у $79(68,7 \pm 4,3) \%$ ураження артерій на Iрунті цукрового діабету типу 2 (OR 0,21, 95\%, CI $0,12-0,36, \mathrm{p}<0,01)$. Виходячи 3 цього, можна вважати, що в період 2010-2014 років основною причиною ампутацій нижньої кінцівки був цукровий діабет типу 2 (табл. 1).

У пацієнтів з облітеруючим атеросклерозом достовірно $(\mathrm{p}<0,001)$ частіше виконували ампутації середньої чи верхньої третини стегна. В жодного 3 них не було виконано ампутацій на рівні колінного суглоба, тоді як у шести хворих була виконана операція Грітті-Шимановського. Тільки у двох пацієнтів виконувались ампутації на рівні гомілки. Ампутації різних відділів стопи достовірно $(\mathrm{p}<0,001)$ частіше проводилися з приводу цукрового діабету типу 2. У 17 пацієнтів виникала потреба у проведенні реампутацій: у трьох після ампутацій на рівні стегна, у двох після ампутацій на рівні гомілки та у дванадцяти - численні реампутації стопи.

Дані про рівень оклюзії визначали на підставі результатів фізикальних обстежень, ультразвукового досліджень та результатів ангіографії (37 пацієнтів). Нами було встановлено, що оклюзія на рівні біфуркації аорти відмічалось у 24 пацієнтів $(20,9 \pm 3,79) \%$, стегнових артерій $38(33,0 \pm 4,39) \%$, у $29(25,2 \pm 4,05) \%$ хворих спостерігалось ураження підколінних та артерій гомілки та у 24 $(20,9 \pm 3,79)$ \% пацієнтів спостерігались множинні локальні оклюзії різних відділів периферійних артерій нижніх кінцівок.

Проспективний eman. Аналізуючи 74 пацієнтів, які були включені у проспективний етап дослідження, нами були виявлені достовірні гендерні відмінності: жінок було $(32,4 \pm 5,4) \%$, проти $(67,6 \pm 5,4) \%$ чоловіків ( $<0,001)$. Серед хворих, які були включені у проспективний етап дослідження, тривалість анамнезу хронічної ішемії нижньої кінцівки перевищувала п’ять років. Вісімнадцять пацієнтів $(24,3 \pm 5,0)$ \% розцінювали терміни початку захворювання в межах від 6 до 10 років, 30

Таблиця 1. Залежність рівня ампутації від основного захворювання в пацієнтів ретроспективного етапу дослідження

\begin{tabular}{||l|c|c|c|c|c||}
\hline $\begin{array}{c}\text { Рівень } \\
\text { ампутації }\end{array}$ & $\begin{array}{c}\text { Облітеруючий } \\
\text { атеросклероз }\end{array}$ & Цукровий діабет & OR & СI & P \\
\hline Стегно & $28(77,8 \pm 6,93 \%)$ & $29(36,7 \pm 5,4 \%)$ & 6,03 & $2,43-14,98$ & $<0,001$ \\
\hline Коліно & - & $6(7,6 \pm 3,0 \%)$ & 0,35 & $0,04-3,000$ & $>0,05$ \\
\hline Гомілка & $2(5,6 \pm 3,82 \%)$ & - & 4,59 & $0,40-52,33$ & $>0,05$ \\
\hline Стопа & $6(16,7 \pm 6,21 \%)$ & $44(55,7 \pm 5,6 \%)$ & 0,16 & $0,06-0,42$ & $<0,001$ \\
\hline Всього & $36(31,3 \pm 4,3 \%)$ & $79(68,7 \pm 4,3 \%)$ & 0,21 & $0,12-0,36$ & $<0,001$ \\
\hline
\end{tabular}


$(40,5 \pm 5,7) \%$ - від 11 до 15 років. Понад 16 років хворіли $(21,6 \pm 4,8) \%$ пацієнтів.

Впродовж 2015-2018 pр. у клініці не було проведено жодної нетравматичної ампутації на рівні гомілки. У пацієнтів з облітеруючим атеросклерозом судин нижніх кінцівок ампутації на рівні стегна виконували у $(40,9 \pm 10,48) \%$ випадків. У 11 пацієнтів $(50,0 \pm 10,66) \%$ виконували ампутації на рівні колінного суглоба за запропонованою нами методикою. Тільки у двох хворих $(9,1 \pm 6,13) \%$ проводили ощадні ампутації на рівні стопи. У 52 пацієнтів з цукровим діабетом типу 2 ампутації на рівні стегна були проведені у $(7,7 \pm 3,7)$ \% випадків. Серед цих хворих переважали ампутації на рівні колінного суглоба $(25,0 \pm 6,0) \%$ та ощадні ампутації стопи $(67,3 \pm 6,5) \%$ (табл. 2$)$.

Таблиця 2. Залежність рівня ампутації від основного захворювання у пацієнтів проспективного етапу дослідження

\begin{tabular}{||l|c|c|c|c|c||}
\hline $\begin{array}{c}\text { Рівень } \\
\text { ампутації }\end{array}$ & $\begin{array}{c}\text { Облітеруючий } \\
\text { атеросклероз }\end{array}$ & Цукровий діабет & OR & CI & P \\
\hline Стегно & $9(40,9 \pm 10,48 \%)$ & $4(7,7 \pm 3,7 \%)$ & 8,31 & $2,20-31,34$ & $<0,01$ \\
\hline Коліно & $11(50,0 \pm 10,66 \%)$ & $13(25,0 \pm 6,0 \%)$ & 3,0 & $1,05-8,53$ & $>0,05$ \\
\hline Стопа & $2(9,1 \pm 6,13 \%)$ & $35(67,3 \pm 6,5 \%)$ & 0,05 & $0,01-0,23$ & $<0,001$ \\
\hline Всього & $22(29,7 \pm 5,31 \%)$ & $52(70,3 \pm 5,3 \%)$ & 0,18 & $0,09-0,36$ & $<0,001$ \\
\hline
\end{tabular}

У більшості госпіталізація пацієнтів як ретроспективного, так і проспективного етапів проводилась в ургентному порядку з діагнозом гангрени стопи. Серед 115 пацієнтів ретроспективного етапу, двадцять один $(18,3 \pm 3,6)$ \% був спрямований з інших стаціонарів після невдалої реконструктивної операції на судинах нижньої кінцівки. Серед пацієнтів проспективного етапу таких було $5(6,8 \pm 2,9) \%$.

Аналізуючи основні дані пацієнтів ретроспективного та проспективного етапів, нами не було встановлено достовірної різниці між віком та статтю. Не відрізнялись достовірно й основні причини хронічної ішемії нижньої кінцівки, які призвели до розвитку некротичних змін: частота облітеруючого атеросклерозу та цукрового діабету у хворих обох етапів була однакова.

Поряд з цим нами відмічено, що у пацієнтів проспективного етапу був менш тривалий анамнез захворювання, яке спричинило оклюзію периферійних артерій $(\mathrm{p}<0,05)$. Достовірно зменшилась кількість пацієнтів, у яких некротичні зміни кінцівки виникали після неефективної відкритої чи ендоваскулярної реконструктивної операції на судинах $(\mathrm{p}<0,05)$. На нашу думку, це пов'язано 3 більш ширшим впровадженням інтервенційних методів реваскуляризації: вони були мало травматичними, легко переносились пацієнтами і можуть виконуватись неодноразово.

В період з 2015 по 2018 рр. зменшилась кількість ампутацій на рівні стегна $(\mathrm{p}<0,001)$, зрос- ла частота ампутацій на рівні колінного суглоба ( $<0,001)$. Враховуючи неефективність ампутацій на рівні гомілки, які виконувались у пацієнтів ретроспективного етапу, у 2015-2018 рр. у клініці від них відмовились при наявності гангрени в умовах неоперабельного оклюзійного артеріального русла. Частота проведення ощадних ампутацій стопи змінилась недостовірно (р>0,05). Недостовірно зменшилась кількість пацієнтів, у яких виникала потреба у реампутаціях (p>0,05).

Серед пацієнтів і ретроспективного і проспективного етапів критична ішемія нижньої кінцівки перебігала на фоні супутньої патології, яка мала значення для визначення ризику оперативного втручання та визначала частоту і тяжкість ускладнень у післяопераційному періоді. Найбільш поширеним були захворювання, пов'язані із генералізованим атеросклерозом: ішемічна хвороба серця, гіпертензія різного генезу, вогнищевий та дифузний кардіосклероз, порушення серцевого ритму, дисциркуляторна енцефалопатія. У пацієнтів часто діагностували емфізему легень та порушення клубочкової фільтрації. Достовірних відмінностей між частотою супутньої патології у пацієнтів ретроспективного та проспективного етапу не спостерігали.

Висновки. 1. Найбільш частою причиною нетравматичних ампутацій кінцівок $є$ цукровий діабет типу 2.

2. В період з 2015 по 2018 рр. зменшилась кількість ампутацій на рівні стегна $(\mathrm{p}<0,001)$ і зрос- 
ла частота ампутацій на рівні колінного суглоба $(\mathrm{p}<0,001)$, а частота проведення ощадних ампутацій стопи змінилась недостовірно ( $>0,05)$. Недостовірно зменшилась кількість пацієнтів, у яких виникала потреба у реампутаціях (p>0,05).

\section{СПИСОК ЛІТЕРАТУРИ}

1. Major lower limb amputation: Outcomes are improving / D. A. Kelly, S. Pedersen, P. Tosenovsky, K. Sieunarine // Ann. Vasc. Surg. - 2017. - Vol. 45. - P. 29-34. doi: 10.1016/j. avsg.2017.05.039.

2. Manning B. J. Lower extremity amputation: Analysis by postcode / B. J. Manning // Eur. J. Vasc. Endovasc. Surg. - 2018. - Vol. 28. pii: S1078-5884(18)30863-3.

3. Shi E. Outcomes of wound healing and limb loss after transmetatarsal amputation in the presence of peripheral vascular disease / E. Shi, M. Jex, S. Patel, J. Garg // J. Foot Ankle Surg. 2019. - Vol. 58 (1). - P. 47-51.

4. Manual and documents of International Working Group on
3. Перспективним у плані подальших досліджень є напрацювання оптимальних методик ампутації нижньої кінцівки залежно від рівня оклюзії у пацієнтів з критичною ішемією нижньої кінцівки.

the Diabetic Foot 2015 for prevention and treatment of diabetic foot diseases: the achievement of argumentative consensus (Russian cut version). Wounds and wound infections / K. Bakker, J. Apelqvist, B. A. Lipsky [et al.] // The Prof. B. M. Kostyuchenok Journal. - 2016. - Vol. 3 (2). - P. 59-70. DOI: 10.17650/24089613-2016-3-2-59-70.

5. Higashi Y. Baseline characterization of Japanese peripheral arterial disease patients - analysis of surveillance of cardiovascular events in antiplatelet-treated arteriosclerosis obliterans patients in Japan (SEASON) / Y. Higashi, T. Miyata, H. ShigematsuFujita, H. Matsuo [et al.] // Circulation Journal. - 2016. - Vol. 80 (3) P. 712 - 721. DOI: 10.1253/circj.CJ15-1048.

\section{REFERENCES}

1. Kelly, D.A., Pedersen, S., Tosenovsky, P., \& Sieunarine, K. (2017). Major lower limb amputation: Outcomes are improving. Ann. Vasc. Surg., 45, 29-34. doi: 10.1016/j.avsg.2017.05.039.

2. Manning, B.J. (2018). Lower extremity amputation: Analysis by postcode. Eur. J. Vasc. Endovasc. Surg., 28. pii: S10785884(18)30863-3.

3. Shi, E., Jex, M., Patel, S., \& Garg, J. (2019). Outcomes of wound healing and limb loss after transmetatarsal amputation in the presence of peripheral vascular disease. J. Foot Ankle Surg., 58 (1), 47-51.

4. Bakker, K., Apelqvist, J., Lipsky, B.A., Van Netten, J.J., \& Schaper, N.C. (2016). Manual and documents of International

Working Group on the Diabetic Foot 2015 for prevention and treatment of diabetic foot diseases: the achievement of argumentative consensus (Russian cut version). Wounds and wound infections. The Prof. B.M. Kostyuchenok Journal, 3 (2), 59-70. DOI: 10.17650/2408-9613-2016-3-2-59-70.

5. Higashi, Y., Miyata, T., Shigematsu, H., Origasa, H., Fujita, M., \& Matsuo, H., et al. (2016). Baseline characterization of Japanese peripheral arterial disease patients- analysis of surveillance of cardiovascular events in antiplatelet-treated arteriosclerosis obliterans patients in Japan (SEASON). Circulation Journal, 80 (3), 712-721. DOI: 10.1253/circj.CJ15-1048.

Отримано 06.11.2019

\section{ANALYSIS OF CLINICAL COURSE AND SURGICAL TREATMENT OF PATIENTS WITH CRITICAL LOWER LIMB ISCHEMIA}

The aim of the work: to analyze the gender, clinical, anamnestic features of the course of occlusive diseases of the lower extremity arteries in patients who had non-traumatic amputations.

Materials and Methods. There were performed analysis of clinical examination and treatment of 189 patients with obliterating diseases of the lower extremity arteries. The retrospective phase of the study included 115 patients who underwent lower extremity amputations at various levels during 2010-2014. The prospective phase of the study included 74 patients in whom lower limb amputation was performed during 2015-2018.

Results and Discussion. The main causes of chronic lower extremity ischemia that led to the development of necrotic changes were not significantly different: the frequency of obliterating atherosclerosis and diabetes in patients at both stages was the same. Patients of the prospective stage had a shorter history of disease $(\mathrm{p}<0.05)$, significantly the number of patients decreased who had an amputation performed after unsuccessful open or endovascular reconstructive surgery on the vessels ( $\mathrm{p}<0.05)$. Amputation at hip level decreased ( $p<0.001)$, knee amputation rate increased ( $<<0.001)$. Frequency of saving foot amputations changed insignificantly ( $>0.05)$. The number of patients requiring re-treatment was significantly reduced $(\mathrm{p}>0.05)$.

Conclusions. The most common cause of non-traumatic limb amputation is type 2 diabetes. Between 2015 and 2018 , the number of amputations above the knee decreased. The number of patients requiring re-treatment was significantly reduced ( $>>0.05$ ).

Key words: occlusive diseases; critical limb ischemia of lower extremity; amputation. 


\section{АНАЛИЗ К.ЛИНЧЕСКОГО ТЕЧЕНИЯ И ОПЕРАЦИОННОГО ЛЕЧЕНИЯ ПАЦИЕНТОВ С КРИТИЧЕСКОЙ ИШЕМИЕЙ НИЖНЕЙ КОНЕЧНОСТИ}

Цель работы: проанализировать гендерные, клинические, анамнестические особенности течения окклюзионных заболеваний артерий нижних конечностей у пациентов, которым были выполнены нетравматические ампутации.

Материалы и методы. Проведенный анализ клинического обследования и лечения 189 пациентов с облитерирующими заболеваниями артерий нижних конечностей. В ретроспективный этап исследования были включены 115 пациентов, которым было проведены ампутации нижних конечностей на разном уровне в течение 2010-2014 гг. Проспективный этап исследования включал 74 пациента, у которых ампутация нижней конечности была проведена в течение 2015-2018 гг.

Результаты исследований и их обсуждение. Достоверно не отличались основные причины хронической ишемии нижних конечностей, которые привели к развитию некротических изменений: частота облитерирующего атеросклероза и сахарного диабета у больных обоих этапов была одинакова. У пациентов проспективного этапа был менее длительный анамнез заболевания ( $<0,05)$, достоверно уменьшилось количество пациентов, у которых ампутацию выполняли после неудачной открытой или эндоваскулярной реконструктивной операции на сосудах (р $<0,05)$. Уменьшилось количество ампутаций на уровне бедра $(\mathrm{p}<0,001)$, возросла частота ампутаций на уровне коленного сустава ( $<0,001)$. Частота проведения сберегательных ампутаций стопы изменилась недостоверно (р> 0,05). Недостоверно уменьшилось количество пациентов, у которых возникала потребность в реампутации (р>0,05). Наиболее частой причиной нетравматических ампутаций конечностей является сахарный диабет типа 2. В период с 2015 по 2018 гг. уменьшилось количество ампутаций выше колена. Недостоверно уменьшилось количество пациентов, у которых возникала потребность в реампутации (р> 0,05).

Ключевые слова: окклюзионные заболевания; критическая ишемия нижних конечностей; ампутация. 